\title{
Parasite Remains in Archaeological Sites
}

\section{Françoise Bouchet, Niéde Guidon*, Katharina Dittmar**/+, Stephanie Harter, Luiz Fernando Ferreira $^{* * *}$, Sergio Miranda Chaves ${ }^{* * *}$, Karl Reinhard ${ }^{* * *}$, Adauto Araújo ${ }^{* * *}$}

Laboratoire de Paléoparasitologie, CNRS ESA 8045, Université de Reims, France *Fundação Museu do Homem Americano, Sã0 Raimundo Nonato, PI, Brasil **Institute of Parasitology, Veterinary Faculty, University of Leipzig, Germany/ Insect Genetics Lab, WIDB 401, Department of Integrative Biology, Brigham Young University, Provo, 84602, Utah, USA ***Escola Nacional de Saúde Pública-Fiocruz, Rio de Janeiro, RJ, Brasil ****School of Natural Research Resources/University of Nebraska, Lincoln

Organic remains can be found in many different environments. They are the most significant source for paleoparasitological studies as well as for other paleoecological reconstruction. Preserved paleoparasitological remains are found from the driest to the moistest conditions. They help us to understand past and present diseases and therefore contribute to understanding the evolution of present human sociality, biology, and behavior. In this paper, the scope of the surviving evidence will be briefly surveyed, and the great variety of ways it has been preserved in different environments will be discussed. This is done to develop to the most appropriated techniques to recover remaining parasites. Different techniques applied to the study of paleoparasitological remains, preserved in different environments, are presented. The most common materials used to analyze prehistoric human groups are reviewed, and their potential for reconstructing ancient environment and disease are emphasized. This paper also urges increased cooperation among archaeologists, paleontologists, and paleoparasitologists.

Key words: paleoparasitology - coprolites - ectoparasites - intestinal parasites - mummies - ancient diseases

Among the ecological factors that influence the density and appearance of a population, parasites and parasitic diseases may play a central role (Cockburn 1967). The presence of a given parasite in a host population may interfere with host dynamics. Paleoparasitological studies can be useful, not only from a medical perspective, but also to understand other past events of human evolution. Parasitism is dependent on environment and behavior. To determine aspects of ancient environment and behavior, it is important to study organic remains in parasitological contexts (Reinhard 1996). This type of analysis shows how cultural development and environment stresses interactions between ancient humans and parasites. These include conditions of hygiene, sanitation, and nutritional adequacy.

Initially, collaboration among parasitologists and archaeologists was random (Reinhard 1992a). Studies were conducted very sporadically when material such as coprolites or mummified bodies were available and submitted to analysis. With the onset of the so called "New Archaeology" in the 1960s in the United States, perspectives of archaeology changed deeply and archaeologists to a large extent turned away from the sole approaches of history towards other sciences. New ideas emerged from other disciplines and multidisciplinary teams appeared. These early multidisciplinary research project involving

Supported by CNPq, Papes-Fiocruz, Capes-Cofecub, and Fulbright Commission.

${ }^{+}$Corresponding author: Fax: +1-801-422.0090. E-mail: katharinad@hotmail.com

Received 26 August 2002

Accepetd 25 November 2002 parasitology are represented by Heizer and Napton (1970), Hevly et al. (1979), and Morris (1986).

Among other branches of paleoecology, paleoparasitology started to undergo a strong development in the past years. Generally, the study of parasite infection in the past has different traditions throughout the world.

In the Americas, there developed two different concepts of paleoparasitological study. In North America archaeologists involved biologists in their work and so sponsored paleoparasitological study. The first North Americans to do parasitological work were trained as archaeologists and interpreted their findings in context of human diet, ecology, and cultural complexity (Fry 1977, 1980, 1985). In the archaeological work at Antelope House and Dust Devil Cave, for example, many biologists of different specialities, including parasitologists, were incorporated (Morris 1986). As this field developed, parasitological data were used to shed light on human cultural evolution through thousands of years of prehistory (Reinhard 1988). For this reason Reinhard (1990) called archaeoparasitology the study of parasites in an archaeological perspective (Reinhard 1990, 1992a; Reinhard et al. 1987). Some years later this approach was extended to Peru and Chile.

The development of paleoparasitology in Brazil in the late 1970s (Ferreira et al. 1988) followed an opposite path relative to the United States. LF Ferreira called paleoparasitology the study of parasites found in archaeological or paleontological material (Ferreira et al. 1979). Here, parasitologists became interested in the antiquity of parasitic diseases, the antiquity of host-parasite relationships, and the prehistoric distribution of parasites (Araújo \& Ferreira 2000). They sought help from archaeologists in procuring coprolites, mummies, hair, and other sources of parasitological information. The interests of Brazilian paleoparasitologists concerned mainly the existing parasitic diseases in the Old World and the New World before Colum- 
bus and prehistoric migrations based on paleoparasitological data (Araújo et al. 1981, Araújo \& Ferreira 1996, Reinhard et al. 2001).

In Europe, there is a long history of analysis of archaeological remains. Mummies were an important source of parasitological evidence, especially "bog bodies" of northern Europe (Helbaek 1958, Glob 1977, Fischer 1998). In mummy studies, the analysis of organic residues was an inherent part of work by interdisciplinary teams. European paleoparasitology groups also developed a vast experience in mediaeval deposits and latrines (Szidat 1944, Taylor 1955, Grzywinski 1960, Bouchet 1997, Bouchet et al. 1995).

In the 1980s, the field of environmental archaeology emerged in England. This field had an important effect in defining the direction of parasitological analysis in England, and in setting standards for a more comprehensive approach to parasitological study (Jones 1982). The research typically includes botanists, malacologists, palynologists, entomologists, parasitologists, and other specialities and the parasitological data are interpreted in context of environment and behavior (Greig 1994).

There is a tendency today for similar environmental approaches to prehistoric parasitism in the Americas and Europe. For example, from the archaeological site of Pedra Furada, Piauí, coprolites dated of 7,000 to 8,500 years old were found to contain plant and pollen remains indicating therapeutic plant use, paleoclimatic, and paleoenvironment conditions (Chame 1988, Chaves 1996, Chaves \& RenaultMiskovsky 1996).

The results of growing cooperation encouraged many archaeologists and paleontologists to search for coprolites and other possible sources of parasite remains. Thus, and a multidisciplinary approach is needed to provide as much additional information about the human population as possible.

\section{PRESERVATION OF PALEOPARASITOLOGICAL REMAINS}

The advent of new techniques (Araújo et al. 1998) and the international communication among paleoparasitologists concerning their research and experiences called attention to the very differing preservation patterns of the paleoparasitological remains in different parts of the world. In a previous paper the experience of American and European paleoparasitologists had been explored (Reinhard et al. 1986). Since then a number of papers regarding parasite findings in human and other animal coprolites have been published.

The conditions that result in the preservation of parasites vary from region to region. Crucial for preservation is the rapid interruption of decay. The preservation of organic material is sometimes limited to places of extreme moisture, high aridity, or frozen conditions. The combination of high and low temperatures, together with dryness, result in rapid desiccation, hindering the activity of catalytic enzymes and destructive microorganisms. Environments of great aridity like deserts are known to provide extraordinary favorable conditions for the preservation of all kinds of organic material (Reinhard 1992). Another possibility of stopping the process of decay of organic material is natural refrigeration, especially useful for a longterm preservation.
Tropical climates are mostly unsuitable for the preservation of organic matter. The combination of heavy rainfall, abundant insect life, and acid soil usually accelerate the process of destruction of organic material. Below we summarize and discuss the conditions that result in the preservation of parasite remains.

\section{THE PARASITES}

The paleoparasite evidence consists mostly of eggs and rarely of larvae (developmental stages) of intestinal parasites, or of the chitinous shells of ectoparasites, such as lice, mites and fleas (Dittmar 2000, Araujo et al. 2000). While some organisms are known to form certain biogenic structures that survive for a long time in a variety of environments (eg. pollen grains), helminth parasite species rarely produce eggs with the same long-lived resistance to environmental stressors. However some parasite species produce protective structures that guard against decay. The eggs of some nematode parasites, such as Ascaridae, Capillaridae, Trichuridae, and Oxyuridae and cestodes (taeniid eggs) are known to have a good chance of recovery.

Thin-walled eggs, such as Enterobius spp. or Strongylus spp. preserve less well. Enterobius vermicularis eggs are especially fragile and sometimes, the decomposition of $E$. vermicularis eggs in the protective structure of a coprolite has been noted. Eggs of this species are also particularly rare in latrine contexts and it is possible that they simply don't survive even short periods of decomposition (see Bouchet et al. this volume).

Another problematic aspect of preservation lies in the lifecycle of some of the parasites. Ancylostomid eggs hatch soon after deposition, and therefore, unless the larvae die before embryonation is complete, eggs will not be found. Ancylostomids have been found in mummies and coprolites, but in latrine sediments there is no definitive identification of eggs or larvae of this type of worm up to now (see Gonçalves et al. this volume). Trichostrongylid eggs hatch after defecation and therefore only special conditions of preservation permit the recovery of parasites in this group. Angiostrongylus presents even more complications in the fact that the eggs hatch in the lungs of the host and the juvenile worms are defecated. Probably, only in mummies would it be possible to identify infections with species of this group. Certain strongyloid parasites present similar problems. Strongyloides stercoralis females, for example, lay eggs which hatch in the intestine before defecation. Only in the best preservation conditions can larvae of this species be found (Reinhard 1985).

Ectoparasites, such as mites, lice and ticks, are rarely found among archaeological material. Usually, if they are not included in amber (see examples in this volume), they require the presence of its former host, human or animal, to be recovered. Nits and eggs can be found attached to the hair shaft or the fur. Ectoparasites and their development stages can be found in preserved clothes, on the scalp, or in associated tools such as combs. Although the chitinous exoskeleton is very resilient to decay, it does not provide good protection from the decay of the inner bodily structures. Therefore, most of the time, only an empty shell is found. 


\section{MICROENVIRONMENTS AND PARASITE PRESERVATION}

It has long been recognized that "microenvironments" promote preservation of organic remains. In the case of parasites, those microenvironments consist mainly of coprolites, latrine soils, preserved hair or fur, and mummified tissues.

\section{Coprolites}

Coprolites are the preserved feces both humans and animals. They can be found everywhere in archaeological or paleontological settings where conditions are suitable for preservation. Coprolites can be mineralized, desiccated, or preserved by anaerobiosis in moist or dry environments. Coprolites are found in archaeological layers, latrine soils, and in the intestines of mummified bodies. Coprolites are the most conspicuous material for paleoparasitologists. Parasite eggs, larvae, and DNA can be recovered from preserved coprolites. In other sites however, when the coprolite deposits are moistened by rainfall, sporadic decomposition takes place in aerobic conditions. The coprolites from these open environments are usually in a poor state of preservation and exhibit extensive evidence of mites, fungal spores, and fungal hyphae. Fungal growth is active in such deposits and at least once, several archaeologists became ill with lung infections of apparent mycological origin while excavating coprolites.

Archaeological and paleontological methods have been developed to collect any suspected biological or cultural remains, but sometimes it may not be easy to recognize a coprolite on an archaeological site. Morphologically, a well-preserved coprolite is not different from recently deposited feces, but they can be fragmented or turned to dust and dissolved in the archaeological layer or in latrine soil. After defecation, feces are exposed to many climatic factors. Rain and humidity can alter fecal morphology, and might result in dispersal of organic contents such as parasite eggs, especially from the surface. Some helminth larvae embryonate, hatch, and leave feces to develop in the soil. Therefore we recommend collecting soil samples from the coprolite vicinity.

\section{Latrine soils and other sediments}

Another source of paleoparasitological material is latrine sediments. Latrine sediments are composed of large amounts of coprolites that already disintegrated in the process of decay. However, at some point the decay process has been interrupted and the contents preserved. Latrine sediments may contain eggs, larvae, or parasite DNA. Sediments present special problems to the archaeologist that can be solved by the parasitologist (Jones 1985). Many times, the identification of fecal sediments, as opposed to trash or natural sediments, can be done by analyzing parasite eggs. Latrine sediments, of any time period, can be dated by associated artifacts. Many archaeological latrine sites are situated in the inner city compound of recent cities or settlements. Water influx can occur from broken pipes and can seriously alter an intact strata setting, transporting parasite eggs from the recent layers to the deeper and older strata. Comparative analyses from samples of all excavated strata are recommended to avoid misinterpretations of data. Associated materials are also an important source for parasitological research. In garbage deposits in house surroundings, discarded medical devices may be found with parasite remains. For example, delousing combs have been found in the Near East with attached lice (Mucuonglu \& Zias 1988). Also, a fragmented clyster was found in a 19th century farm cesspit near Rio de Janeiro. It contained Ascaris lumbricoides eggs (LF Ferreira, data not published).

Soil samples from the pelvic region of skeletons can be submitted to analysis. It is important to know whether the burial is an undisturbed or disturbed one, and in what position the body was found lying. Methods for sample burial were developed by Reinhard et al. (1992). Only a few reports exist so far, but the recovery of parasite eggs was successful (see Dittmar \& Teegen this volume).

\section{Mummified bodies}

A 3,200 year-old Egyptian mummy was the first case of an infectious disease made by finding a parasite egg (Ruffer 1910). Mummies are representatives of ancient populations and lives throughout the world. They can be found from the most dry to moister environments. Some mummies are artificially prepared and others are naturally preserved by environmental conditions. Mummies may be naturally preserved in Africa, Asia, American deserts, in calcareous caves in tropical climates, or in the freezing climate of arctic glaciers.

Mummies were prepared for different religious and cultural reasons and by different methods in different parts of the world. Therefore, not all artificially mummified bodies have the same potential for parasitological analysis. Human mummies are better known, but mummified animals are also existent, most commonly from the Egypt and the Andes (Guillen, pers. commun.).

Although rare, mummified bodies are an important source for paleoparasitology. One of the best known parasite discoveries found in a mummified body were Ancylostoma duodenale adults found in such a wonderful state of preservation, that it was possible to make histological sections of the ancient worms feeding on the intestinal mucosa of the mummy (Allison et al. 1974).

With mummies, unlike coprolites and latrine soils, the host is immediately known. Parasite eggs and larvae found in mummy intestinal contents can be more easily identified than those found in coprolites or sediments. As any other organic remain, mummified bodies may be found in any archaeological region. Examples of exceptional preservation are the bog sites (Szidat 1944, Nansen \& Joergensen 1977) in England, Denmark, North Germany, and other north European regions. Anaerobic and highly acid conditions contributed to preserve human bodies. Studies of the remaining contents of the intestinal tract not only revealed interesting data from the paleobotanical point of view but also about parasitic diseases. The analysis of food remains in Lindow Man for instance revealed large numbers of whipworm eggs (Brothwell 1987). Also the intestinal content of bog-people known as Grauballe Man, Tollund Man and the Drobnitz Girl contained parasite eggs (Fischer 1998). Human bodies from ancient and recent times have been found in the Alaskan 
Arctic where natural catastrophes resulted in the rapid freezing of people (Zimmermann 1998). The Italian Ice Man (Ötzi) is perhaps the best-known case of cessation of decay. An Inca mummy, known as Juanita, was discovered in the Andean mountains and is one of several Inca mummies that have been preserved by freezing (Vreeland $\mathrm{Jr}$ 1998). Among other well-known finds are the Pazyryk bodies in the Altai mountains (Hart Hansen 1998). Several reports of parasitic eggs exist from the finds mentioned above (Zimmerman 1998, Bouchet et al. 1999, Aufderheide \& Rodríguez-Martín 1998).

\section{TECHNIQUES OF RECOVERY}

\section{Retrieving the evidence from the archeological setting}

As with any archaeological material, paleoparasitological remains must be clearly dated by current methods. They should be recovered like any other organic material. However, methods of recovery can vary according to the research question. We recommend the use of gloves during excavation when aDNA-analysis is to be conducted. As molecular biology technologies are increasingly employed, it is wise to take care with all organic material during excavation, and prevent bare hand contact. To avoid premature and uncontrolled rehydration, excavated samples should be stored in dry conditions.

It is important to know whether a setting was undisturbed or disturbed. Also, with latrine sediments, a control sample should be taken from the near environment, to screen for possible contamination with recent parasites.

Special care must be taken with insect fragments. Museum cleaning of mummies and artifacts such as clothing should always be preceded by a thorough analysis for ectoparasites. When ectoparasites and other arthropods are found, they should be stored in $70-100 \%$ ethanol in a refrigerator. The best method for transport is the "vial in a vial" method. With this method, ectoparasites are collected with a feather-weight-pincett (jeweler's forceps) and stored in a small vial. This vial is filled with ethanol and closed with cotton and then inserted into a screw lid, tight-seal vial which is also filled with ethanol and thoroughly closed. This method is used by most entomologists to prevent the loss of morphologically important features.

\section{Sorting out the evidence}

For the recovery of parasites from coprolites, Callen and Cameron (1960) applied a trisodium phosphate rehydration technique. The coprolite is submerged in $0.5 \%$ trisodium phosphate, until completely dissolved. Samuels (1965) evaluated this technique at different concentrations of trisodium phosphate and confirmed that the $0.5 \%$ solution was best. The method was subsequently applied by Fry (1977) and it became the standard practice for rehydrating desiccated tissue. Reinhard et al (1986) experimented with various flotation and sedimentation techniques and determined that sedimentation methods of different types were best for desiccated remains.

Because of the similarity of parasite egg preservation to pollen preservation, parasitological analysis procedures for sediments have been derived from palynological processing techniques. Hevly et al. (1979) were the first researchers to discover that many types of nematode and cestode eggs could be recovered through palynological processing. Their methods of laboratory recovery involved sequential digestion of sediments in weak base $(\mathrm{NaOH})$, and several concentrated acids (hydrochloric acid, hydrofluoric acid, and acetic acid), and finally acetolysis solution (eight parts acetic anhydride to one part sulfuric acid). This method was experimentally applied to modern feces positive for trichurids, ascarids, taeniids, and clonorchids (Reinhard et al. 1986). However, it was found that the acetolysis solution dissolved eggs. Subsequently, a method was developed to recover parasite eggs derived from palynological processing (Reinhard et al. 1986, Warnock \& Reinhard 1994). This method excludes the base and adds a period of sonication. However, in practice, it is better to process first in hydrochloric acid without sonication and subsequently hydrofluoric acid. If it is possible to count parasite eggs after hydrochloric acid treatment alone, then the hydrofluoric acid treatment is omitted for safety reasons. A quantification method originally developed for geological palynology and later applied to archaeological palynology is applicable to paleoparasitology (Reinhard et al. 1990, Warnock \& Reinhard 1994). It consists in the addition of known numbers of exotic spores to sediment sample. The parasite eggs are then counted in reference to a fixed Spore Reference Index and calculations of the number of eggs per gram of sediment can be made. Jones (1982) in England used a modified Stoll's technique with latrine sediments. This method proved to be a very good quantification technique, especially for sediments that had egg concentrations exceeding 400 eggs/g.

In France, Bouchet et al. (1999) developed a slightly different method. Samples are rehydrated for 3 to 5 weeks in the $0.5 \%$ aqueous trisodium phosphate solution. A 5\% glycerinated solution is added and the material is then crushed in a mortar. The suspension is treated in ultrasonic device (Sonorex 103K) at $60^{\circ} \mathrm{C}$ for 1 min under 3,000 rpm and strained through $315-\mathrm{mm}, 160-\mathrm{mm}, 50-\mathrm{mm}$, and $25-\mathrm{mm}$ meshes. The last two screenings are treated with flotation (densities 1.04 to 1.4) and sedimentation (1,500 rpm for $5 \mathrm{~min}$ ) techniques.

Ectoparasites can be subjected to regular mounting techniques, used for modern insects. Dittmar (2001) found an initial clearing of arthropod chitinous structures with $1 \% \mathrm{NaOH}$ for $1 / 2 \mathrm{hrs}$ worked best. Mounting can be done with BERLESE solution or a glycerin-gelatine based medium.

\section{PROBLEMS IN THE INTERPRETATION OF THE DATA}

Even if parasite eggs are found, their identification sometimes imposes serious problems to the researcher and limits the resolution of paleoparasitological analysis (Reinhard 1998). Sometimes, tapeworm eggs are morphologically similar between species and it is impossible to diagnose a specific infection. The inability to diagnose Taenia solium from Taenia saginata is a frustrating problem in certain cultural contexts. For example, taeniid eggs were found in a latrine in Jerusalem dating 2.586 years ago, during the Babylonian siege of the city of David. If it would be possible to determine which species of taeniid 
eggs was present, it might be possible to infer when the Jewish prohibition of pork began. The only possibility to solve this problem would be through the use of molecular techniques.

Diphylobothrium species are also difficult to diagnose from eggs, because of the similarity of eggs between species in the genus and with other genera. However, eggshell microstructure morphology can help with identification, especially using scanning electron microscopy (see Bouchet et al. this volume). In other cases, Diphyllobothrium eggs could be easily identified to the species level (Ferreira et al. 1984, Reinhard \& Urban this volume).

Fortunately, the identification of the general taxa of flukes that infect humans is less of a problem. Egg morphology is relatively distinct and has allowed the diagnosis of Fasciola hepatica, Clonorchis sinensis, Paragonimus westermani and the three species of Schistosoma spp., that infect humans.

Another problem is estimating the epidemiological consequences of infection. Due to a number of diagenetic factors influencing the parasitological remains, it is not easy to assess the true parasitic load of an individual at the time of death. Therefore the data, calculated from an archeological setting, can only be treated as an estimation of prevalence and researchers have to acknowledge that a paleoepidemiology in sensu latu is hardly achieved (see Mendonça de Souza et al. this volume, for a discussion of limits and perspectives of paleoepidemiological studies). However, there is a hope that this will change. Reinhard and Buikstra present paleoepidemiological data that approximate modern patterns (this volume). We anticipate that molecular biology will provide supporting epidemiological inferences for the past.

A new research approach emerged from the cooperation of archaeologists and paleontologists with paleoparasitologists. From this cooperation, a broader picture of infectious diseases and their distribution is being defined from parasite remains. We anticipate that this international communication between parasitologists, and the established interaction between archaeologists and parasitologists, will evolve into a strong development of paleoparasitology and into an archaeology of parasitism. We anticipate that future field excavations will be geared towards analysis of biological remains, and indications of behavior that promoted or limited parasitism. This may include the excavation of sediments for the recovery of vectors of parasites as well as the parasites themselves.

\section{REFERENCES}

Allison MJ, Pezzia A, Hasegawa I, Gerszten E 1974. A case of hookworm infection in pre-Columbian America. Am J Phys Anthropol 41: 103-106.

Araújo A, Ferreira LF 1996. On hookworms and transpacific contact. Parasitol Today 12: 454.

Araújo A, Ferreira LF 2000. Paleoparasitology and the antiquity of human host-parasite relationships. Mem Inst Oswaldo Cruz 95 (Suppl. I): 89-93.

Araújo A, Ferreira LF, Confalonieri U 1981. A contribution to the study of helminth findings in archaeological material in Brazil. Rev Bras Biol 41: 873-881.

Araújo A, Ferreira LF, Guidon N, Freire NMS, Reinhard K, Dittmar K 2000. Ten thousand years of head lice infection.
Parasitol Today 7: 269.

Araújo A, Reinhard K, Bastos OM, Cantarino LM, Pirmez C, Iñiguez A, Vicente AC, Morel CM, Ferreira LF 1998. Paleoparasitology: perspectives with new techniques. Rev Inst Med Trop São Paulo 40: 371-376.

Aufderheide AC, Rodrigues M 2001. The Cambridge Encyclopedia of Human Paleopathology, Cambridge Univ. Press, Cambridge, p. 245-246.

Bouchet F 1997. Intestinal capillariasis in neolithic inhabitats of Chalain (Jura, France). Lancet 349: 256.

Bouchet F, Paicheler JC 1995. Paléoparasitologie: présumption d'un cas de bilharziose au XV $\mathrm{XV}^{\mathrm{eme}}$ siècle à Montbéliard (Douls, France). CR Acad Sci Paris 318: 811-814.

Bouchet F, Lefévre C, West D, Corbertt D 1999. First paleoparasitological analysis of a midden in the Aleutian Islands (Alaska): results and limits. J Parasitol 85: 369-372.

Brothwell D 1987. The Bog Man and the Archaeology of People, Brit Mus Publ, London, 128 pp.

Callen EO, Cameron TWM 1960. A prehistoric diet as revealed in coprolites. New Sci 8: 35-40.

Chame M 1988. Estudo Comparativo das Fezes e Coprólitos Não Humanos da Região Arqueológica de São Raimundo Nonato, Sudeste do Piauí, MSc Thesis, Museu Nacional/ UFRJ, Rio de Janeiro

Chaves SM 1996. Metodologia utilizada para extração de pólen de coprólitos humanos: estudo comparativo. Rev Mus Arqueol Etnol São Paulo 6: 394-395.

Chaves SM, Renault-Miskowsky J 1996. Paléoethnologie, paléoenvironnement et paléoclimatologie au Piauí, Brésil: apport de l'étude pollinique de coprolites humains recuillis dans le gisement préhistorique Pléistocène de "Pedra Furada". CR Acad Sci Paris 322: 1053-1060.

Cockburn A 1967. Infectious Diseases: Their Evolution and Eradication, Thomas, Springfield.

Dittmar K 2000. Ectoparasites on guinea pig mummies of El Yaral, Chungara. Rev Antrop Chil 32: 123-127.

Dittmar K 2001. Untersuchungen zum Vorkommen von Ektoparasiten bei domestizierten und wildlebenden Meerschweinchen (Cavia spp.) sowie an präinkaischen Meerschweinchenmumien in Peru, Südamerika, Thesis, University of Leipzig, Leipzig, $160 \mathrm{pp}$.

Ferreira LF, Araújo A, Confalonieri U 1979. Subsídios para a paleoparasitologia do Brasil. I - Parasitos encontrados em coprólitos no município de Unaí, Minas Gerais. Res Congr Bras Parasitol, Campinas, SP, p. 56.

Ferreira LF, Araújo A, Confalonieri U 1988. Paleoparasitologia no Brasil, PEC/ENSP/Fiocruz, Rio de Janeiro, 158 pp.

Ferreira LF, Araújo A, Confalonieri U, Nuñez L 1984. The finding of eggs of Diphyllbothrium in human coprolites (4, 000-1,950 B.C.) from Northern Chile. Mem Inst Oswaldo Cruz 79: 175-180.

Fischer C 1998. Bog bodies of Denmark and Northwestern Europe. In A Cockburn, E Cockburn, TA Reyman (eds), Mummies, Disease and Ancient Cultures, 2nd ed., Cambridge Univ Press, Cambridge, p. 237-262.

Fry GF 1977. Analysis of Prehistoric Coprolites from Utah, Anthropol Papers, 97, Univ. Utah, 45 pp.

Fry GF 1980. Prehistoric diet and parasites in the Desert West of North America. In DL Browman, Early Native Americans, Moutin Press, The Hague, p. 325-339.

Fry GF 1985 Analysis of fecal material. In The Analysis of Prehistoric Diets, Academic Press, New York.

Glob PV 1969. The Bog People, Cornell Univ Press, Ithaca, NY.

Greig J 1994. Pollen analysis of latrine fills from archaeological sites in Britain; results and future potential. Ann Assoc Stratigr Palynol 29: 101-114.

Grzywinski L 1960. Analysis of feces from the Middle Age 
period. Zool Pol 10: 195-199.

Hart Hansen JP 1998. Bodies from cold regions. In A Cockburn, E Cockburn, TA Reyman (eds), Mummies, Disease, and Ancient Cultures, Cambridge Univ. Press, Cambridge, p. 336-350.

Heizer RF, Napton 1970. Archaeology and the prehistoric Great Basin lacrustrin subsistence regime as seen from Lovelock Cave, Nevada. Contributions 10, University of California Archeological Research Facility, California.

Helbaek H 1958. Studying the diet of ancient man. Archaeology 14: 95-101.

Hevley RH, Kelly RE, Anderson GA, Olsen SJ 1979. Comparative effects of climate change, cultural impact, and volcanism in the paleoecology of Flagstaff, Arizona, A.D. 9001300. In P Sheets, D Grayson (eds), Volcanic Activity and Human History, Academic Press, New York, p. 487-523.

Jones AKG 1982. Human parasite remains: prospects for a quantitative approach. In AR Hall, HK Kenwards (eds), Environmental Archaeology in the Urban Context, Res Report n. 43, Counc British Archaeol, p. 66-70.

Jones AKG 1985. Trichurid ova in archaeological deposits: their value as indicators of ancient faeces. In NRJ Fieller, DD Gilbertson, N Ralph (eds), Palaeobiological Investigations. Reseach Design, Methods and Data Analysis, Symposia of the Association for Environmental Archaeology 5B, British Archaeological Reports International Series 226, p. $105-115$.

Morris DP 1986. Archaeological Investigations at Antelope House, National Park Service, Washington. D.C.

Mumcluogu YK, Zias J 1988. Head lice, Pediculus humanus capitis (Anoplura, Pediculidae) from hair combs excavated in Israel and dated from the first century B.C. to the eight century A.D. J Med Entomol 25: 545-547.

Nansen P, Jorgensen RJ 1977. Parasite eggs identified in material from archaeological excavations in Ribe (The Viking Age). Nord Vet Med 29: 263-266.

Reinhard KJ 1985. Strongyloides stercoralis in the Prehistoric southwest. In CF Merbs, RJ Miller (eds), Health and Disease in the Prehistoric Southwest, Arizona State University Anthropological Research Papers 34, Tempe, p. 234-242.

Reinhard KJ 1988. The cultural ecology of prehistoric parasitism on the Colorado Plateau as evidenced by coprology. Am J Physical Anthropol 77: 355-366.

Reinhard KJ 1990. Archaeoparasitology in North America. Am J Phys Anthropol 82: 145-163.
Reinhard KJ 1992a. Parasitology as a tool for the archaeologist. Am Antiquity 57: 231-245.

Reinhard KJ 1992b. The impact of diet, and parasitism on anemia in the prehistoric West. In P Stuart-McAdam, S Kent (eds), Demography and Disease: Changing Perspectives of Anemia, Aldine de Gruyter, New York, p. 219-258.

Reinhard KJ 1998. Parasitology. In A Cockburn, E Cockburn, TA Reyman (eds), Mummies, Disease, and Ancient Cultures, Cambridge Univ. Press, Cambridge, p. 377-380.

Reinhard K, Araújo A, Ferreira LF, Coimbra JR CE 2001. American hookworm antiquity. Med Anthropol 20: 97-101.

Reinhard KJ, Confalonieri U, Herrmann B, Ferreira LF, Araújo A 1986. A recovery of parasite remains from coprolites and latrines: aspects of paleoparasitological techniques. Homo 37: 2117-239.

Reinhard KJ, Geib PR, Callahan MM, Hevly RH 1992. Discovery of colon contents in a skeletonized burial: soil sampling for dietary remains. J Archaeol Sci 19: 697-705.

Reinhard KJ, Hevly RH, Anderson GA 1987. Helminth remains from prehistoric Indian coprolites from the Colorado Plateau. J Parasitol 70: 630-639.

Rufler MA 1910. Note on the presence of Bilharzia haematobia in Egyptian mummies of the Twentieth Dynasty (1250$1000 \mathrm{Bc})$. Br Med Jr 1: 16.

Samuels R 1965. Parasitological study of long-dried fecal samples. In D Osborne, BS Katz (eds), Contributions to the Wetherill Mesa Archaeological Project. Mem Soc Amer Archaeol 19: 175-179.

Szidat L 1944. Uber die Erhaltungsfähigkeit von Helmintheneierm in Vor-und frühgeschchtlichen Moorleichen. Z Parasitenkd 13: 265-274.

Taylor EL 1955. Parasitic helminths in mediaeval remains. Vet Rec 67: 216-218.

Vreeland Jr 1998. Mummies of Peru. In A Cockburn, E Cockburn,TA Reyman (eds), Mummies, Disease, and Ancient Cultures, Cambridge Univ. Press, Cambridge, p. 154189.

Warnock P, Reinhard KJ 1994. Methods of extracting pollen and parasite eggs from latrine soils. J Archaeol Sci 19:261264.

Zimmerman MR 1998. Aleutian and Alaskan mummies. In A Cockburn, E Cockburn E, TA Reyman (eds), Mummies, Disease, and Ancient Cultures, Cambridge Univ. Press, Cambridge, p. 138-153. 